\title{
"Oh Wow. Oh Wow. Oh Wow" Ontological Contexts and Transconceptual Interpretations of Death and Dying
}

\author{
Mary Cappelli \\ Independent Interdisciplinary Scholar
}

\begin{abstract}
In this paper, I examine Apple Founder Steve Job's final words "Oh wow. Oh wow. Oh wow" as uttered to his half-Sister Mona Simpson as a framework to explore how pre-experiential linguistic, social, and ontological patterns shape and construct consciousness and expressions at the final moment of death. Final words of passage provide society with insight into the experience of being human in the transition from life to death, both in their limitations and in their potential for providing a continuous fluidity of transformation. Understanding how these final words are transconceptual experiences will encourage us to reflect on alternative interpretative possibilities sensitive to ontological and logical contexts of death and dying providing a holistic alternative framework which is more congruent with individual spiritual needs.
\end{abstract}

Keywords: ontology, death, dying, Steve Jobs

\section{Introduction}

Final words have had what Karl Rahner refers to as an axiological presence in literature, biographies, and scientific research since Julian of Norwich recognized them as expressions of "preparation of the soul for death and afterlife" (Fenwick, Lovelace, and Brayne, 1). Ontological articulations on the nature of death prompted Leo Tolstoy's character Ivan Ilych to ask, "So where shall I be when I am no more?" (Kramer, 15) Ivan Ilych answered his own question when he saw the light beyond death and said, "So that's what it is. What Joy! Death is finished. It is no more!" (Kramer, 15) Elizabeth Barrett Browning sighed, "Beautiful," to her husband who was by her side at her final hour, and James Joyce questioned, "Does nobody understand?" (Smith) No, Mr. Joyce; yet, we desperately seek understanding for as Walt Whitman observed, final words of passage are "valuable beyond measure to confirm and endorse the varied train, facts, theories, and faith of the whole preceding life" (Whitman, 409). Hence, it is no wonder why people are fascinated with Steve Jobs's last words to his sister Mona Simpson: "Oh wow. Oh wow. Oh wow” (Tsukayama). Upon hearing (reading) Steve Jobs’s final words, we are naturally curious as to whether these final two words, symbolically repeated three times, can grant us any insight about our human experience and what happens at the moments preceding death. It is my position that an examination of the socio-cultural and sacred context of final utterances can facilitate an understanding of the interplay of phenomenological interpretations. Moreover, consideration of an individual's ontological framework will enhance our abilities to provide complementary palliative care, which is more congruently intuitive with the individual spiritual needs of the dying.

Mary Cappelli, Ph.D., JD, Former Lecturer Emerson College, USA; main research field: Interdisciplinary Studies, Ethnography, Legal Anthropology, and Literature. 


\section{The Ontology of “Oneness"}

As a hippie, New Age Californian, I was born the same year as Steve Jobs and explored similar Eastern Mysticism from Hinduism, Self-realization, to Buddhism. I have lived by Bob Dylan's lyric mantra, "He's not busy being born is busy dying," which is the Zen way of saying: One, who dies before dying, never dies again. And Steve Jobs's way of saying in what many Buddhists consider to be his final Dharma talk at Stanford, "Remembering that I'll be dead soon is the most important tool I've ever encountered to help me make the big choices in life." Jobs affirms the belief of many spiritual leaders from the Dalai Lama to Socrates that the practice of dying is a supreme form of knowledge. Jobs, like Socrates on his deathbed, understands that "death is one of the most profoundly healing acts of a lifetime;" therefore, we should "always be occupied in the practice of dying," as death awakens us to live more single-mindedly in the present moment (Levine, 138).

Timothy Leary knew the importance of surrender to the present moment and poignantly repeated in his final words that instead of treating death in terms of fear and helplessness, we should change our perceptions surrounding the death process. "We should think of it as a triumphant graduation in which family and friends can celebrate, discuss, plan for the final moment" (Leary, 100). Leary's advice is not new, as Elisabeth Kübler Ross, Stephen Levine, and many other palliative theorists have long advocated for dying with awareness, dignity, and emotional openness.

Many cultures have reported final words of passage as part of the dying process; yet, there is limited research that has examined the ontological frameworks of the dying and the bereaved who have reported the final words. Final words of passage have been reported in Fenwick, Lovelace, and Brayne's research on end of life experiences to have substantive value and profound personal meaning for both the dying and the bereaved. Their studies suggest that end of life phenomenon and final words are common shared experiences. The commonality of a core death experience gives further credibility to Elisabeth Kübler-Ross's research on death awareness and her intra-psychic five-stage process of grief, which has become normative in terms of its universal application to all death experiences.

Universal claims about how dying is constructed also extend to mystical core experiences. Scharfstein, Maslow, Nhat Hanh, Goswami, and others identify a quality of "oneness" as a significant feature of mystical experience often referred to as a cosmic absolute with the universal matrix, or any essence stipulated by the various theological and speculative systems of the world (Bregman, 64). The essence of oneness also seems to possess universal attributes of ineffability, paradoxicality, and unity with all things. Constructions of universality and notions of mystical core experiences have often been held suspect by theorists, particularly Wayne Proudfoot who refutes the universality of core experiences first posited by James and Otto. Proudfoot argues, "The diversity of our emotional experience must rather be a function of the complexity of the concepts and thoughts that can enter into that experience" (76). In this sense, dying is not a mindless activity and calls into playing cognitive conceptions and intellectual constructions of reality. Whether death experiences are exclusive or inclusive of intellectual processes and socio-cultural and physical constructions, the intellect informs the interpretation of the experience. The varied ontology of oneness evidences a multiplicity of meaning in doctrinal interpretations and these qualitative and connotative variations call into question whether or not multiple signifiers genuinely reflect a distinct interpretation of a signified oneness.

Discussions of whether or not "Oh wow," contain a signified essence of oneness, who begs the more fundamental discussion that needs to recognize the myriad ontological interpretations of "oneness." In this 
sense, words and images, which evoke a transition from life to death, while culturally and ontologically bound, are radically different from those meanings found in conventional death and dying practices. According to Jobs, "Intuition is a very powerful thing, more powerful than intellect, in my opinion" (Isaacson, 48).

Steve Jobs acknowledged this deep complexity of non-cognitive processes when he traveled through India's countryside observing how the people lived with more of an intellect of the heart and spirit than with the mind. Ironically, it is because of their technological seclusion from the overcrowded information highways that people are more in tune with their environment and have a keener sense of intuition. The gathering of more and more information on the quest for knowledge is akin to lightening streaking across a dark sky; after it flashes, it's swallowed by the darkness. Jobs reflects:

Western rational thought is not an innate human characteristic; it is learned and is the great achievement of Western civilization. In the villages of India, they never learned it. They learned something else, which is in some ways just as valuable but in other ways is not. That's the power of intuition and experiential wisdom. (Isaacson, 48)

While Jobs's spiritual journey straddled the polarities between theoretical knowledge and direct knowledge through meditation and self-realization, he acknowledged the power of intellect on his life and work (Isaacson, 48). When he returned from India, he continued to practice mindfulness meditation synthesizing his practice in India with a disciplinary approach of "mind technology" to enhance his lucidity and creativity. According to Jobs, the practice of meditation can bring awareness to the restless state of the mind.

If you try to calm it, it only makes it worse, but over time it does calm, and when it does, there's room to hear more subtle things - that when your intuition starts to blossom and you start to see things more clearly and be in the present more. Your mind just slows down, and you see a tremendous expanse in the moment. You see so much more than you could see before. (Isaacson, 49)

Before his death, Jobs had developed a regular practice of mindfulness meditation. Synthesizing Buddhism, Hinduism, and "mind technology," Jobs recognized the importance of experiential wisdom and an awakened mind capable of seeing through worldly delusions to grasp truth and reality. Accordingly, it is through the forgetting of selfhood that an individual releases his bond with his ego to become one with his surroundings (Suzuki, 69). There, within the losing of oneself in the darkened expanse of the Indian, sky shines the possibility of profound hope and understanding for humanity.

\section{The Essence of Being}

The transition from life to death begins a shift in consciousness between being and nonbeing that unlocks access to the intuitive and mystical aspects of existence, which transcends conventional final words of passage of shared physical reality. At this stage of life, theoretical concepts and analytical constructs need to be integrated and synthesized with non-cognitive subjective and spiritual intuition on the nature of existence. Words of passage during this transitional shift represent a radical alterity from conventional language. While all mystical awareness becomes significant in light of the differences in the soteriological expectations that are described or evoked through the assumptions about the use of language, conventional use of language carries assumptions about its capacity to partially describe and to evoke transconceptual awareness. The examination of language to describe these shifts in consciousness and patterns of transcendence reveals different ontological meanings assigned to the similar experience of what has been described as "space," "light," "nothingness," and "emptiness." 
Religious patterns and symbolism of transcendent imagery of "light" and "space" begin to appear in 600 B.C. in the 108 Hindu texts of the Upanishads whose central message reveals a realization of attman. The immortal quality of self, symbolic of the macrocosm in each of us, is Brahman, sacred word, or sacred power. The open space and diffusion of the atmosphere and the expanse of the sky symbolize Brahman. According to Mahayana Buddhism, man through his participation in Brahman, is coextensive with the universe. Immortal self and sacred power are two sides of the same reality. The real self is a deathless, unchanging eternal self that is one with the divine transcendent power of Brahman. Yet, the nature of ātman is beyond the intellect and five senses and cannot be explained or described in conventional language. Although ātman is located in all of us, we cannot know it or understand it adequately with our ordinary senses. Sense and mental activity are imperfect instruments widening the polarity and preventing the realization and experience of atman. For Hindus, acknowledgement and actualization of the eternal self is the sacred art of dying. Thus, a Hindu interpretation of "Oh wow" carries with it a sacred immortal essence of being.

This is a quite different interpretation from the perspective of spiritual leader Paramahansa Yogananda and author of Autobiography of a Yogi, the only book Steve Jobs downloaded on his iPad 2 and, according to Isaacson, reread on a yearly basis. Synthesizing Hinduism and Christianity, Yogananda provides alternative ways for understanding death and the sacred art of dying. His teachings encourage individuals to view death as an experience of peace and freedom, and "to laugh in the face of death for in reality as man is essentially of incorporeal nature. There is no death" (157). Yogananda's description of dying contains similar universal attributes of mystical core experience; albeit, the melting of everything in spirit shares some similar ontological qualities of Hindu essence of oneness, there is a clear distinct difference in interpretation. For Yogananda, oneness is the realization of the soul's true nature, the infinite merging of his consciousness with the Creator, often referred to as Christ-Krishna consciousness with the realization that his being has merged with the omnipresence of God. "Through the divine eye in the forehead (east), the yogi sails his consciousness into omnipresence, hearing the word or aum, divine sound of many waters" (Yogananda, 170).

In one of his final interviews with his biographer Walter Isaacson, Steve Jobs pondered the existence of God saying, "I'm about fifty-fifty on believing in God. For most of my life, I've felt that there must be more to our existence than meets the eye" (Isaacson, 571). According to Isaacson, Jobs's metaphysical inquiry led to further studies of "the basic precepts of Eastern religions, such as the emptiness on experiential prajna, wisdom, or conventional understanding that are intuitively experienced through concentration of the mind" (48). Zen Buddhism had a great influence on Jobs's life.

His Buddhist philosophy is captured in the story of Kisa Gotami who grieved and suffered for the loss of her ten-year old son and recognizes, "This only is the law, that all things are impermanent" (Kramer, 44). Gotami awakened to the sacred art of dying before dying and the "Region of the Deathless," an unchanging universal whole, which is beyond death, recognized in Dylan's contemporary lyrics as, "He's not busy being born is busy dying." This is the Buddhist state of Nirvana - where the individual is liberated from the physical sting of death, and the cycle of rebirth and re-death. A person who experiences the unchangeable constant flux of life, the impermanence of being, and the ever-changing reality of all phenomenon reaches Enlightenment and becomes eternally present (Kramer, 47).

In Buddhism, the concept of "ontological Emptiness" or "sunyata" is that no pure essence exists for the basis of anything and all life and matter exists because of its interdependency. Emptiness is a co-dependent and co-arising absorption of all and everything and the annihilation of selfhood and identity, as there is no real self 
and no transcendental self. In this ever-changing shift of being and consciousness, doctrinal canons and external teachings do not apply. In fact, Buddhists are encouraged to surrender their dependence on doctrines of any kind since theories only attract alternative theories leading to further theoretical confusion. The Buddhist view of "being" is that all individual constructions and concepts are projections of the mind, which themselves are impermanent and conditional. Ultimately, life is a continual process of transformation of ever changing consciousness.

A Buddhist interpretation of "Oh wow" suggests that the thoughts and mental condition of a dying person are profound undifferentiated psycho-physical configurations destitute of multiplicity. The implication is that "Oh wow" has according to the Mahayana Context, "no form, nor deeds, no rising, nor falling" as everything arises from emptiness. Thus, emptiness transcends all relationships. In Shunryu Suzuki's Zen Mind Beginner's Mind (an influential book for Steve Jobs), "when we say something, our subjective intention or situation is always involved. So there is no perfect word; some distortion is always present" (75). Words such as "Oh wow" are meaningful only in each moment as according to Suzuki, "There is no continuity between the comprehension of absolute emptiness and the discriminating mind in relative experience; we can know the former only by leaping or plunging into the silent valley of absolute emptiness" (147). In this sense, the space between life and death empties the mind of duality where all binaries and competing theories and ideologies drop away, which is the Buddhist way of saying: om gate gate paragate parasamgate bodhi swaha. Gone, gone, gone beyond, gone altogether beyond, completely exposed, awake. So be it. Or, maybe Steve Jobs way of saying: "Oh wow. Oh wow. Oh wow."

\section{Solace for the Dying}

Research into final words of passage offers insight into the experience of being human in the transition from life to death, both in its limitations and in its potential for providing a continuous fluidity of transformation. Understanding how these final words are transconceptual experiences can have meaningful effects for both the dying patient and his/her family support systems. Moreover, empathetic consideration will encourage reflection on alternative interpretative possibilities sensitive to ontological and logical contexts of death and dying providing a holistic alternative framework-one that is more congruent with individual spiritual needs. Providing palliative care that acknowledges individual ontological frameworks can comfort the dying by assuaging fears, comforting depression, and encouraging acceptance. "Acceptance, in this context, equals 'letting go,' de-cathexis, so that in Kubler-Ross's own language the circle of life may close” (Bregman, 59).

\section{Works Cited}

Bregman, Lucy. “Dying: A Universal Human Experience?” Journal of Religion and Health 28.2 (1989): 58-69. Web., 8 Nov., 2015.

Dylan, Bob. “It’s Alright, Ma (I'm Only Bleeding).” Bringing It All Back Home. Columbia, 1965. CD.

Fenwick, Peter, Lovelace Hilary, and Sue Brayne. "Comfort for the Dying: Five Year Retrospective and One Year Prospective Studies of End of Life Experiences.” Archives of Gerontology and Geriatrics. 22 Sept., 2009. Web., 8 Nov., 2014.

Goswami, Amit. Physics of the Soul: The Quantum Book of Living, Dying Reincarnation and Immortality. Charlottesville: Hampton Roads Publishing Company, 2001.

Jobs, Steve. "American Rhetoric: Steve Jobs-Commencement Address at Stanford University." American Rhetoric: The Power of Oratory in the United States. n.p. 12 June, 2005. Web., 12 Nov., 2015.

Kramer, Kenneth. The Sacred Art of Dying: How the World Religions Understand Death. Mahwah: Paulist Press, 1988. 
Leary, Timothy. Design for Dying. San Francisco: Harper Edge, 1997.

Levine, Stephen. Healing into Life and Death. New York: Anchor, 2010.

Maslow, A. H. "Cognition of Being in the Peak Experiences." Society and Self: A Reader in Social Psychology. New York: Free Press, 1962. 43-66.

Naht Hanh, Thich. The Miracle of Mindfulness: A Manual of Meditation. Boston: Beacon Press, 1976.

Proudfoot, Wayne. Religious Experience. Berkeley: University of California Press, 1985. 76.

Scharfstein, Ben-Ami. A Comparative History of World Philosophy: From the Upanishads to Kant. Albany: State University of New York Press, 1998.

Smith, David. "Real Last Words from Famous People.” Mapping.com.

Suzuki, Shunryu. Zen Mind, Beginner’s Mind. Boston: Shambhala Publications, 1987.

Tsukayama, Hayley. "Steve Jobs's Last Words: ‘Oh wow. Oh wow. Oh wow.” Washington Post. 31 Oct., 2011.

Whitman, Walt. “Good-Bye My Fancy.” The Walt Whitman Archive. n.d. Web., 7 Dec., 2015. 